\title{
Studi Penurunan Kandungan Besi Organik dalam Air Tanah dengan Oksidasi $\mathrm{H}_{2} \mathrm{O}_{2}-\mathrm{UV}$
}

\author{
Rohmatun $^{1}$, Dwina Roosmini ${ }^{2}$ \& Suprihanto Notodarmojo ${ }^{1}$ \\ ${ }^{1}$ Kelompok Keahlian Rekayasa Air dan Limbah Cair \\ ${ }^{2}$ Kelompok Keahlian Teknologi Pengelolaan Lingkungan \\ Fakultas Teknik Sipil dan Lingkungan, Institut Teknologi Bandung \\ Jl. Ganesha No.10, Bandung 40132
}

\begin{abstract}
Abstrak. Fe(II) terlarut dapat bergabung dengan zat organik dan membentuk senyawa kompleks yang sulit untuk dihilangkan dengan aerasi biasa. Salah satu teknologi alternatif untuk menghilangkan besi tersebut adalah dengan Advanced Oxidation Processes (AOPs) yang dapat menghasilkan radikal hidroksil $(\mathrm{OH} \bullet)$. $\mathrm{OH}$ radikal yang terbentuk mempunyai potensial oksidasi yang tinggi sehingga diharapkan mampu mengoksidasi senyawa besi kompleks zat organik. Penelitian ini bertujuan untuk mengetahui efisiensi penurunan besi menggunakan $\mathrm{H}_{2} \mathrm{O}_{2}$ UV, kinetika reaksi yang terjadi, dan melihat pengaruh masing-masing faktor serta interaksi setiap faktor terhadap reaksi oksidasi besi melalui uji statistik. Penelitian ini dilakukan secara batch dengan variasi konsentrasi besi total awal: 3, 5, dan $10 \mathrm{mg} / \mathrm{l} ; \mathrm{Fe}: \mathrm{H}_{2} \mathrm{O}_{2}=1: 5,1: 8$, dan 1:10 (mol/mol); dengan perlakuan menggunakan UV $3 \times 10$ watt dan tanpa UV. Hasil penelitian menunjukkan bahwa kombinasi $\mathrm{H}_{2} \mathrm{O}_{2}$-UV $3 \times 10$ watt memberikan efisiensi penurunan besi yang paling baik pada dosis $\mathrm{Fe}: \mathrm{H}_{2} \mathrm{O}_{2}=1: 5$, yaitu $99 \%$ dan $\mathrm{H}_{2} \mathrm{O}_{2}$ menghasilkan efisiensi paling baik pada dosis $\mathrm{Fe}: \mathrm{H}_{2} \mathrm{O}_{2}=1$ : 8, yaitu 84\%. Semakin besar konsentrasi besi total awal semakin kecil persen penurunan besi. Tetapi tidak selamanya penambahan dosis $\mathrm{H}_{2} \mathrm{O}_{2}$ akan meningkatkan efisiensi. Sedangkan sinar UV memberikan pengaruh yang lebih besar terhadap oksidasi besi apabila dikombinasikan dengan $\mathrm{H}_{2} \mathrm{O}_{2}$. Reaksi oksidasi besi ini menghasilkan orde pertama-semu untuk penurunan besi kompleks zat organik dan konstanta laju reaksi semakin besar apabila oksidasi menggunakan $\mathrm{H}_{2} \mathrm{O}_{2}$-UV 3 x10 watt. Proses oksidasi dengan $\mathrm{H}_{2} \mathrm{O}_{2}$-UV $3 \times 10$ watt ini akan menghasilkan persen penurunan Fe-R sebesar $67 \%$ setelah diujikan pada air sumur di daerah Bandung.
\end{abstract}

Kata Kunci: air tanah; besi; hidrogen peroksida; hidroksil radikal; kinetika reaksi; sinar ultraviolet.
Abstract. Dissolved Fe (II) can react with organic matters and form complex compounds which difficult to be eliminated by ordinary aeration. One of alternative technology to eliminate the dissolved iron is by using Advanced Oxidation Processes (AOPs) which can yield hydroxyl radicals $(\mathrm{OH} \bullet)$. The formed hydroxyl radicals have higher oxidation potential than chlorine and potassium permanganate so that expected able to oxidize organic-iron complexes. The aims of this research are to know the efficiency of iron removal by using $\mathrm{H}_{2} \mathrm{O}_{2}$-UV oxidation, reaction kinetics that happened, and to observe the influence of each factor and also interaction of each factor towards reaction

Makalah diterima redaksi tanggal 30 Juni 2006, revisi diterima tanggal 16 April 2007, diterima untuk diterbitkan tanggal 16 April 2007. 
oxidize iron through statistically tested. This research is conducted in batch with the variation of total iron concentration early: 3, 5, and $10 \mathrm{mg} / \mathrm{l}$; dosage of Fe: $\mathrm{H}_{2} \mathrm{O}_{2}=1: 5,1: 8$, and 1:10 (mole/mole); with treatment use UV $3 \times 10$ watt and without UV. The result of this research indicate that use of combining $\mathrm{H}_{2} \mathrm{O}_{2}-\mathrm{UV}$ $3 \times 10$ watt, with $1: 5$ dosage of $\mathrm{Fe}: \mathrm{H}_{2} \mathrm{O}_{2}$, gave the maximum iron removal of $99 \%$ and the use of $\mathrm{H} 2 \mathrm{O} 2$ with $1: 8$ dosage of $\mathrm{Fe}: \mathrm{H}_{2} \mathrm{O}_{2}$, gave maximum iron removal $84 \%$. If the total early iron concentration increases, the removal of iron concentration will decrease. But addition dosage of $\mathrm{H}_{2} \mathrm{O}_{2}$ will not improve efficiency. While UV ray give great influence to iron oxidation if being combined with $\mathrm{H}_{2} \mathrm{O}_{2}$. Oxidation of this iron show pseudo-first order reaction and its rate constant (k) increases if the oxidation uses $\mathrm{H} 2 \mathrm{O} 2-\mathrm{UV} 3 \times 10$ watt. Oxidation process by $\mathrm{H}_{2} \mathrm{O}_{2}-\mathrm{UV} 3 \times 10$ watt will yield removal of $\mathrm{Fe}-\mathrm{R}$ is $67 \%$ after application at Bandung area ground water.

Keywords: hydroxyl radicals; hydrogen peroxide; iron in ground water; reaction kinetics; ultraviolet ray.

\section{Pendahuluan}

Air tanah sering mengandung besi dalam jumlah yang cukup besar, yaitu 1$10 \mathrm{mg} / 1$ [1]. Adanya kandungan besi dalam air menyebabkan warna air tersebut berubah menjadi kuning-coklat setelah beberapa lama kontak dengan udara. Disamping dapat mengganggu kesehatan, juga menimbulkan bau yang kurang enak dan menyebabkan warna kuning pada dinding bak serta bercak-bercak kuning pada pakaian. Ion besi akan memberikan rasa amis dalam air dan memberi kesempatan tumbuhnya bakteri pengguna besi di dalam sistem distribusi. Oleh karena itu menurut Kepmenkes RI No.907/Menkes/SK/VII/ 2002 tanggal 29 Juli 2002 tentang syarat-syarat dan Pengawasan Kualitas Air, didalam sistem penyediaan air minum kandungan besi dibatasi sampai $0,3 \mathrm{mg} / \mathrm{l}$ [2].

Banyak cara yang telah dilakukan untuk menghilangkan besi dalam air minum, antara lain dengan cara oksidasi, koagulasi, pertukaran ion, serta filtrasi kontak menggunakan media mangan zeolit dan karbon aktif. Tetapi cara yang diterapkan tersebut masih belum memuaskan karena besi yang ditemui berada dalam bentuk senyawa organik dan koloid, misalnya bersenyawa dengan zat warna organik atau asam humus (humic acid). Keadaan demikian sulit dihilangkan baik dengan cara aerasi, penambahan klorin, maupun dengan penambahan kalium permanganat. Adanya partikel-partikel halus $\mathrm{Fe}(\mathrm{OH})_{3} \cdot n \cdot \mathrm{H}_{2} \mathrm{O}$ dalam air juga sulit mengendap dan menyebabkan air menjadi keruh [2].

Salah satu alternatif teknologi pengolahan yang diduga dapat digunakan untuk menghilangkan kandungan besi yang bersenyawa dengan zat organik dalam air 
adalah dengan Advanced Oxidation Processes-AOPs. Proses ini merupakan proses reaksi oksidasi secara kimiawi yang menggunakan hidrogen peroksida $\left(\mathrm{H}_{2} \mathrm{O}_{2}\right)$ sebagai oksidator yang menghasilkan radikal bebas untuk penghilangan senyawa besi yang tidak dapat dihilangkan dengan oksidasi khlorida $\left(\mathrm{Cl}_{2}\right)$ maupun dengan permanganat $\left(\mathrm{MnO}_{4}^{-}\right)$. Prosesnya dapat menggunakan sinar UV sebagai sumber energi untuk reaksi ataupun tidak menggunakan sinar UV.

Hidrogen peroksida pertama kali diproduksi secara komersial pada tahun 1880 dengan membakar garam Barium menjadi Barium Peroksida dan dilarutkan dalam air menghasilkan $\mathrm{H}_{2} \mathrm{O}_{2}$. Dalam perkembangannya $\mathrm{H}_{2} \mathrm{O}_{2}$ diproduksi dalam skala lebih besar dengan metode auto oksidasi dengan menggunakan hidrogen sebagai bahan baku. Dalam penggunaannya $\mathrm{H}_{2} \mathrm{O}_{2}$ mempunyai keuntungan, yaitu: aman, selektif, kuat, serbaguna, dan penggunaannya luas. Penelitian yang telah dilakukan menunjukkan bahwa kombinasi sinar ultraviolet dan hidrogen peroksida dapat menurunkan surfaktan pada air limbah [3]. Menurut Jones [4], $\mathrm{H}_{2} \mathrm{O}_{2} / \mathrm{UV}$ telah diaplikasikan untuk remidiasi air sumur dari beberapa kontaminan di daerah Amerika Utara dan Eropa.

Pada penelitian ini menerapkan proses oksidasi lanjut yang menggunakan kombinasi sinar Ultraviolet (UV) dengan Hidrogen peroksida $\left(\mathrm{H}_{2} \mathrm{O}_{2}\right)$. Karena kombinasi ini akan menghasilkan hidroksi radikal $(\mathrm{OH} \cdot)$ yang dapat mengoksidasi besi kompleks zat organik. Hidroksi radikal ini merupakan salah satu spesimen kimia yang paling reaktif di bawah flourine, sehingga diharapkan mampu menurunkan kandungan besi dalam air tanah.

Tujuan dari penelitian ini adalah untuk mengetahui efisiensi penurunan kandungan besi dengan oksidasi kimia menggunakan hidrogen peroksida dan kombinasi sinar UV-hidrogen peroksida, kinetika reaksi yang terjadi, serta melihat pengaruh masing-masing faktor dan interaksi setiap faktor terhadap reaksi oksidasi besi melalui uji statistik.

\section{Metodologi Penelitian}

Penelitian terdiri atas dua tahap, yaitu penelitian pendahuan dan penelitian utama. Penelitian pendahuluan dilakukan untuk mendapatkan kondisi oksidasi besi menggunakan $\mathrm{H}_{2} \mathrm{O}_{2}$ dan $\mathrm{H}_{2} \mathrm{O}_{2}+\mathrm{UV}$ serta waktu reaksi oksidasi. Penelitian utama dilakukan dengan beberapa variasi faktor, yaitu: konsentrasi besi total awal $(3,5 \& 10 \mathrm{mg} / \mathrm{l})$, konsentrasi $\mathrm{H}_{2} \mathrm{O}_{2}$ yang digunakan $\left(\mathrm{Fe}: \mathrm{H}_{2} \mathrm{O}_{2}=1: 5\right.$, 1:8,\&1:10 (mol/mol)), dengan perlakuan UV $3 \times 10$ watt dan tanpa UV. Bahan kimia yang dibutuhkan yaitu: $\mathrm{H}_{2} \mathrm{O}_{2} 35 \%$, bahan pembuatan senyawa besi kompleks zat organik, dan EDTA sebagai zat organik yang bergabung dengan besi. 
Reaktor oksidasi yang digunakan terdiri dari selubung reaktor dimana dinding dalam reaktor tertempel 3 buah lampu UV 10 watt. Selubung luar reaktor berukuran: diameter atas $30 \mathrm{~cm}$ dan diameter bawah $43,5 \mathrm{~cm}$, tinggi $45 \mathrm{~cm}$. Selubung ini digunakan sebagai penutup reaktor fotolisis. Bagian dalamnya (reaktor fotolisis) terdiri dari stirer dan beaker glass 2 ltr lengkap dengan tutupnya sebagai tempat terjadinya reaksi.

Analisa besi menggunakan metode spektrofotometri. Analisa besi berdasarkan Standar Methods for The Examination of Water \& Wastewater 20 ${ }^{\text {th }}$ Edition [5].

\section{Hasil Dan Pembahasan}

Untuk mencari kondisi reaksi oksidasi besi dilakukan percobaan pendahuluan dengan variasi tanpa $\mathrm{H}_{2} \mathrm{O}_{2}+\mathrm{UV}$ (aerasi biasa), UV $3 \times 10$ watt, $\mathrm{H}_{2} \mathrm{O}_{2}, \mathrm{H}_{2} \mathrm{O}_{2}+\mathrm{UV}$ 10 watt, dan $\mathrm{H}_{2} \mathrm{O}_{2}+\mathrm{UV} 3 \times 10$ watt terhadap konsentrasi besi awal $5 \mathrm{mg} / 1$ selama 180 menit. Hasilnya terlihat pada Tabel 1 . Dari tabel tersebut terlihat bahwa oksidasi tanpa $\mathrm{H}_{2} \mathrm{O}_{2}+\mathrm{UV}$ atau dengan aerasi biasa menghasilkan persen penurunan besi kompleks zat organik yang kecil. Kemudian dicoba dengan menggunakan radiasi sinar UV 3x10 watt, persen removal Fe-EDTA hanya mengalami sedikit peningkatan. Kemudian dilakukan percobaan dengan menambahkan $\mathrm{H}_{2} \mathrm{O}_{2}$, dimana dosisnya sesuai dengan stoikiometri reaksi yang terjadi, Fe: $\mathrm{H}_{2} \mathrm{O}_{2}=1: 10$ (mol/mol). Dari penambahan $\mathrm{H}_{2} \mathrm{O}_{2}$ ini menghasilkan penurunan yang jauh lebih besar. Dan ketika $\mathrm{H}_{2} \mathrm{O}_{2}$ dikombinasikan dengan UV 10 watt maka removal Fe-EDTA meningkat lagi, apalagi setelah daya lampu dinaikkan menjadi $3 \times 10$ watt maka persen removalnya ikut meningkat. Dari tabel ini juga dapat dilihat bahwa waktu yang dibutuhkan untuk oksidasi menggunakan $\mathrm{H}_{2} \mathrm{O}_{2}$ saja adalah 180 menit, jika menggunakan $\mathrm{H}_{2} \mathrm{O}_{2}+\mathrm{UV} 3 \times 10$ watt maka waktunya 60 menit.

Tabel 1 Hasil oksidasi besi pada berbagai kondisi.

\begin{tabular}{|c|c|c|c|c|c|c|}
\hline \multirow{2}{*}{$\begin{array}{c}\text { waktu } \\
\text { reaksi } \\
\text { (menit) }\end{array}$} & \multirow{2}{*}{$\begin{array}{c}\text { Fe total } \\
\text { awal } \\
\text { (ppm) }\end{array}$} & \multicolumn{5}{|c|}{ Removal Fe-EDTA (\%) } \\
\hline & & $\begin{array}{c}\operatorname{tanpa} \\
\mathrm{H}_{2} \mathrm{O}_{2}+\mathrm{UV}\end{array}$ & $\begin{array}{c}\mathrm{UV} \\
3 \times 10 \mathrm{w}\end{array}$ & $\mathbf{H}_{2} \mathbf{O}_{2}$ & $\begin{array}{c}\mathrm{H}_{2} \mathrm{O}_{2}+\mathrm{UV} \\
10 \mathrm{w}\end{array}$ & $\begin{array}{c}\mathrm{H}_{2} \mathrm{O}_{2}+\mathrm{UV} \\
3 \times 10 \mathrm{w}\end{array}$ \\
\hline 0 & 5 & 0,000 & 0,000 & 0,000 & 0,000 & 0,000 \\
\hline 60 & 5 & 6,293 & 8,812 & 36,213 & 92,481 & 92,054 \\
\hline 120 & 5 & 11,830 & 12,838 & 68,431 & 92,453 & 94,088 \\
\hline 180 & 5 & 11,970 & 13,228 & 72,036 & 92,481 & 94,005 \\
\hline
\end{tabular}

Untuk mencari berapa dosis optimum $\mathrm{Fe}: \mathrm{H}_{2} \mathrm{O}_{2}$ yang digunakan maka dilakukan percobaan dengan variasi $\mathrm{Fe}: \mathrm{H}_{2} \mathrm{O}_{2}=1: 3,1: 5,1: 8,1: 10$, dan 1:15 menggunakan $\mathrm{UV}+\mathrm{H}_{2} \mathrm{O}_{2} 3 \times 10$ watt. Dari hasil percobaan tersebut (seperti dalam Gambar 1) 
didapatkan dosis optimum untuk oksidasi $5 \mathrm{mg} / \mathrm{l}$ besi menggunakan $\mathrm{H}_{2} \mathrm{O}_{2}+\mathrm{UV}$ $3 \times 10$ watt adalah $15,179 \mathrm{mg} / 1\left(\mathrm{Fe}: \mathrm{H}_{2} \mathrm{O}_{2}=1: 5\right)$.

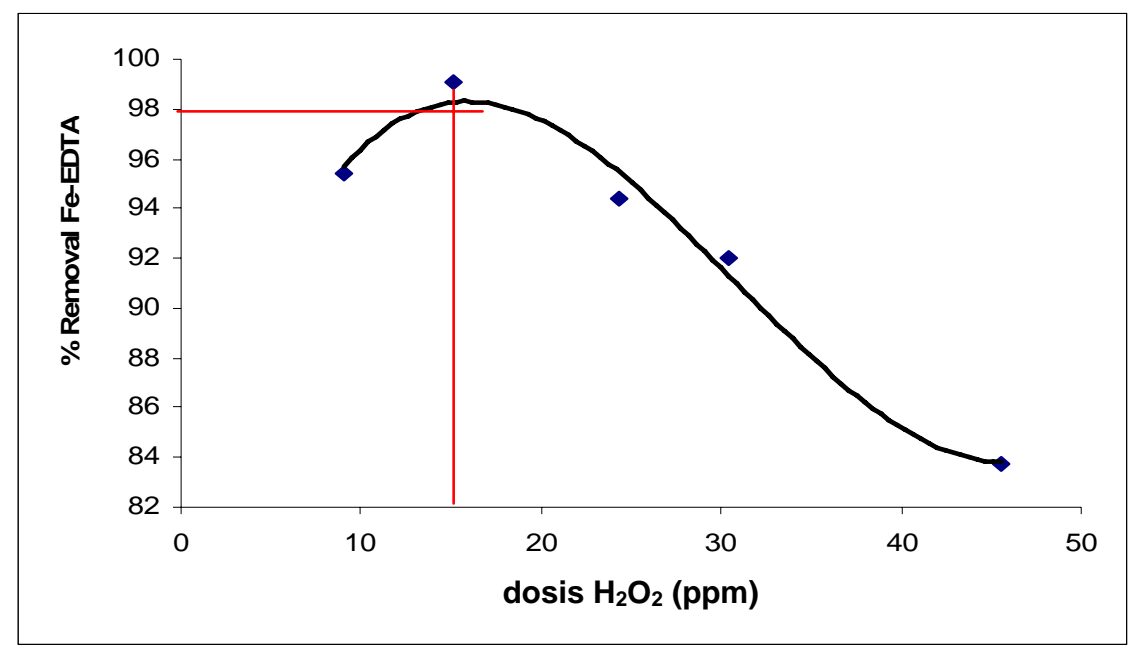

Gambar 1 Mencari dosis $\mathrm{H}_{2} \mathrm{O}_{2}$ optimum.

Percobaan utama menggunakan variasi besi total awal 3, 5, dan $10 \mathrm{mg} / \mathrm{l}$; $\mathrm{Fe}: \mathrm{H}_{2} \mathrm{O}_{2}=1: 5,1: 8$, dan 1:10; perlakuan: tanpa UV dan UV 3x10 watt. Reaksi oksidasinya selama 60 menit jika menggunakan $\mathrm{H}_{2} \mathrm{O}_{2}+\mathrm{UV} 3 \times 10$ watt dan 180 menit jika menggunakan $\mathrm{H}_{2} \mathrm{O}_{2}$ saja. Dari hasil analisa multifaktorial didapatkan bahwa $\mathrm{H}_{2} \mathrm{O}_{2}, \mathrm{UV}$, dan $\mathrm{Fe}$ awal berpengaruh terhadap penurunan besi kompleks zat organik.

Dari hasil pengujian didapatkan bahwa semakin besar konsentrasi besi total awal maka semakin kecil persen penurunan Fe-EDTA baik dengan UV maupun tidak, begitu juga dengan tiga variasi $\mathrm{Fe}: \mathrm{H}_{2} \mathrm{O}_{2}$. Hal ini dapat terjadi karena dalam waktu yang sama, beban proses oksidasi akan semakin besar jika kontaminan yang akan dihilangkan semakin besar. Sehingga dibutuhkan waktu oksidasi yang lebih lama untuk memperoleh persen penurunan konsentrasi yang lebih tinggi.

Percobaan dengan perlakuan tanpa UV merupakan percobaan untuk mendapatkan pengaruh $\mathrm{H}_{2} \mathrm{O}_{2}$ terhadap oksidasi besi kompleks zat organik. Dari hasil percobaan ini diadapatkan bahwa $\mathrm{H}_{2} \mathrm{O}_{2}$ dapat mengoksidasi senyawa besi kompleks zat organik baik untuk konsentarsi besi total awal 3, 5, atau $10 \mathrm{mg} / 1$. Penurunan konsentrasi Fe-organik dengan $\mathrm{H}_{2} \mathrm{O}_{2}$ disebabkan oleh adanya jumlah oksigen yang cukup untuk mengoksidasi besi yang bergabung dengan zat organik, dimana pertama kali oksigen akan memecah ikatan besi-zat organik 
sehingga besi (ferro) akan teroksidasi menjadi ferri sedangkan zat organik akan terurai menjadi $\mathrm{CO}_{2}$ dan air. Sumber oksigen tersebut dapat diperoleh dari disosiasi $\mathrm{H}_{2} \mathrm{O}_{2}$ menjadi $\mathrm{H}_{2} \mathrm{O}$ dan oksigen seperti pada persamaan berikut [6]:

$$
\mathrm{H}_{2} \mathrm{O}_{2} \rightarrow 2 \mathrm{H}_{2} \mathrm{O}+\mathrm{O}_{2}
$$

Penambahan $\mathrm{H}_{2} \mathrm{O}_{2}$ yang berlebih akan mengakibatkan persen penurunan besi kompleks zat organik menjadi tidak optimal. Dalam reagen Fenton [7], apabila dalam air mengandung besi (II) kemudian ditambah dengan $\mathrm{H}_{2} \mathrm{O}_{2}$ maka kedua zat tersebut akan bereaksi menjadi $\mathrm{Fe}(\mathrm{III}), \mathrm{HO}^{-}$dan $\mathrm{OH}^{\bullet}$. Jika $\mathrm{H}_{2} \mathrm{O}_{2}$ berlebih maka $\mathrm{OH}$ radikal yang terbentuk akan bereaksi dengan $\mathrm{H}_{2} \mathrm{O}_{2}$ dan menghasilkan $\mathrm{HO}_{2} \bullet$ Sehingga $\mathrm{OH}$ radikal tidak efektif lagi dalam memecah ikatan kompleks besi dengan zat organik. Selain itu penambahan $\mathrm{H}_{2} \mathrm{O}_{2}$ yang berlebih akan menimbulkan dampak yang lain pula, disamping bersifat toksik, $\mathrm{H}_{2} \mathrm{O}_{2}$ yang berlebih akan menambah kandungan zat organik dalam air. Untuk itu perlu dicari dosis optimum $\mathrm{H}_{2} \mathrm{O}_{2}$ untuk oksidasi besi dengan $\mathrm{H}_{2} \mathrm{O}_{2}$. Oksidasi besi menggunakan $\mathrm{H}_{2} \mathrm{O}_{2}$ akan menghasilkan penurunan besi kompleks zat organik antara $60-84 \%$. Pada Tabel 2 dapat dilihat hubungan konsentrasi besi total awal, dosis $\mathrm{H}_{2} \mathrm{O}_{2}$ pada oksidasi menggunakan $\mathrm{H}_{2} \mathrm{O}_{2}$ selama 3 jam saat persen penurunan Fe-EDTA maksimum.

Tabel 2 Hubungan konsentrasi besi total awal dengan dosis $\mathrm{H}_{2} \mathrm{O}_{2}$ pada oksidasi menggunakan $\mathrm{H}_{2} \mathrm{O}_{2}$.

\begin{tabular}{cccc}
\hline \multirow{2}{*}{$\begin{array}{c}\text { Fe awal } \\
(\mathbf{m g} / \mathbf{l})\end{array}$} & \multicolumn{3}{c}{ Fe:-EDTA } \\
\cline { 2 - 4 } $\mathbf{O}_{\mathbf{2}}$ & Dosis $\mathbf{H}_{\mathbf{2}} \mathbf{O}_{\mathbf{2}}$ & $\mathbf{\% R}$ \\
\hline 3 & $1: 08$ & 14,579 & 83,653 \\
5 & $1: 08$ & 24,286 & 80,666 \\
10 & $1: 05$ & 30,43 & 73,768 \\
\hline
\end{tabular}

Dari tabel tersebut terlihat bahwa semakin besar konsentrasi besi total awal maka semakin besar pula dosis $\mathrm{H}_{2} \mathrm{O}_{2}$ yang dibutuhkan. Karena kandungan kontaminan makin besar sehingga memerlukan oksidator yang makin besar pula. Dan dosis Fe: $\mathrm{H}_{2} \mathrm{O}_{2}=1: 8$ memberikan persen terbesar untuk penurunan FeEDTA.

Persen penurunan besi kompleks zat organik akan semakin meningkat jika oksidasi menggunakan $\mathrm{H}_{2} \mathrm{O}_{2}+\mathrm{UV} 3 \times 10$ watt. Teknologi penggabungan $\mathrm{H}_{2} \mathrm{O}_{2}+\mathrm{UV}$ ini merupakan proses oksidasi kimia lanjut yang menggunakan $\mathrm{H}_{2} \mathrm{O}_{2}$ sebagai bahan oksidator dan sinar UV digunakan sebagai energi untuk memecah $\mathrm{H}_{2} \mathrm{O}_{2}$ menjadi $\mathrm{OH}$ radikal. Hidroksil radikal bisa terbentuk ketika sinar UV (200-280 nm) dipancarkan ke dalam air yang mengandung $\mathrm{H}_{2} \mathrm{O}_{2}$. Reaksi yang ditunjukkan merupakan reaksi fotolisis dari $\mathrm{H}_{2} \mathrm{O}_{2}$, seperti yang terlihat berikut ini [8]: 


\section{Rohmatun, Dwina Roosmini \& Suprihanto Notodarmojo}

$$
\mathrm{H}_{2} \mathrm{O}_{2}+\mathrm{UV}(\text { atau } h v, \lambda \approx 200-280 \mathrm{~nm}) \rightarrow \mathrm{HO}^{\circ}+\mathrm{HO}^{\circ}
$$

$\mathrm{HO}^{\circ}$ adalah bentuk spesimen yang dibangkitkan karena kehilangan satu elektron sehingga sangat tidak stabil. Ketidakstabilan spesimen ini akan langsung bereaksi dengan senyawa kimia yang kontak dengan $\mathrm{HO}^{\circ}$ ini dan akan mengoksidasi dengan sempurna senyawa organik dan anorganik yang terlarut [3].

$\mathrm{OH}$ radikal yang telah terbentuk selanjutnya akan memecah ikatan kompleks besi(II) dan zat organik. Selanjutnya $\mathrm{OH}$ radikal tersebut akan mengoksidasi besi(II) menjadi besi(III) yang mudah diendapkan. Selain itu $\mathrm{OH}$ radikal juga akan mengoksidasi zat organik menjadi senyawa yang lebih sederhana atau akan menjadi karbondioksida, air, dan garam mineral jika terjadi reaksi oksidasi yang sempurna. Diduga mekanisme oksidasi besi (II) dan zat organik (R) adalah sebagai berikut [6]:

$$
\begin{aligned}
& \mathrm{H}_{2} \mathrm{O}_{2}+h v \rightarrow 2 \mathrm{OH} \bullet \\
& \mathrm{OH} \bullet+\mathrm{Fe}(\mathrm{II}) \rightarrow \mathrm{Fe}(\mathrm{III})+\mathrm{OH}^{-} \\
& \mathrm{OH} \bullet+\mathrm{RH} \rightarrow \mathrm{CO}_{2}+\mathrm{H}_{2} \mathrm{O}+\text { garam mineral }
\end{aligned}
$$

Variasi pemberian dosis $\mathrm{H}_{2} \mathrm{O}_{2}$ memberikan gambaran bahwa pembentukan $\mathrm{OH}$ radikal akan semakin besar jika jumlah atau konsentrasi $\mathrm{H}_{2} \mathrm{O}_{2}$ yang ditambahkan makin besar. Meskipun penambahan dosis $\mathrm{H}_{2} \mathrm{O}_{2}$ yang lebih besar dapat mempercepat pembentukan hidroksi radikal, namun perlu dipertimbangkan sisa $\mathrm{H}_{2} \mathrm{O}_{2}$ pada akhir proses oksidasi, sebab tidak semua $\mathrm{H}_{2} \mathrm{O}_{2}$ dapat berubah menjadi hidroksi radikal dalam waktu radiasi yang pendek [3]. Selain itu $\mathrm{OH}$ radikal akan bereaksi dengan $\mathrm{H}_{2} \mathrm{O}_{2}$ yang berlebih menjadi $\mathrm{HO}_{2}$ • yang tidak reaktif dibanding $\mathrm{OH} \bullet$.

Tabel 3 Hubungan konsentrasi besi total awal dengan dosis $\mathrm{H}_{2} \mathrm{O}_{2}$ pada oksidasi menggunakan $\mathrm{H}_{2} \mathrm{O}_{2}+\mathrm{uv} 3 \times 10$ watt.

\begin{tabular}{cccc}
\hline Fe awal & \multicolumn{3}{c}{ Fe-EDTA } \\
\cline { 2 - 4 }$(\mathbf{m g} / \mathbf{l})$ & $\mathbf{F e}: \mathbf{H}_{\mathbf{2}} \mathbf{O}_{\mathbf{2}}$ & Dosis $\mathbf{H}_{\mathbf{2}} \mathbf{O}_{\mathbf{2}}$ & $\mathbf{\% R}$ \\
\hline 3 & $1: 08$ & 14,579 & 99,595 \\
5 & $1: 05$ & 15,179 & 99,079 \\
10 & $1: 05$ & 30,43 & 78,512 \\
\hline
\end{tabular}

Hasil oksidasi untuk penurunan Fe-EDTA maksimum saat menggunakan $\mathrm{H}_{2} \mathrm{O}_{2}+\mathrm{UV} 3 \times 10$ watt hasilnya dapat dilihat pada Tabel 3. Semakin besar kadar besi total awal maka $\mathrm{H}_{2} \mathrm{O}_{2}$ yang digunakan semakin besar. Dan nilai removal terbesar untuk penurunan Fe-EDTA terjadi pada $\mathrm{Fe}: \mathrm{H}_{2} \mathrm{O}_{2}=1: 5$. 
Dari hasil pembahasan di atas terlihat bahwa untuk oksidasi besi kompleks zat organik akan mendapatkan hasil optimal jika menggunakan $\mathrm{H}_{2} \mathrm{O}_{2}+\mathrm{UV} 3 \times 10$ watt dengan $\mathrm{Fe}: \mathrm{H}_{2} \mathrm{O}_{2}=1: 5$ karena jika menggunakan $\mathrm{H}_{2} \mathrm{O}_{2}$ saja maka dosisnya akan menjadi lebih besar yaitu $\mathrm{Fe}: \mathrm{H}_{2} \mathrm{O}_{2}=1: 8$ selain itu nilai penurunannya lebih besar dan waktunya lebih pendek. Hal ini dapat terjadi karena radiasi sinar ultraviolet akan memecah $\mathrm{H}_{2} \mathrm{O}_{2}$ menjadi dua hidroksi radikal yang menyebabkan spesimen ini mempunyai potensial oksidator yang lebih besar dari $\mathrm{H}_{2} \mathrm{O}_{2}$ [3].

Tabel 4 Hasil perhitungan orde reaksi penurunankonsentrasi Fe-EDTA.

\begin{tabular}{ccccccc}
\hline $\begin{array}{c}\text { Feawal } \\
\text { (mg/l) }\end{array}$ & $\begin{array}{c}\text { Fe: } \mathbf{H}_{\mathbf{2}} \mathbf{O}_{2} \\
\text { (mol/mol) }\end{array}$ & $\begin{array}{c}\text { UV } \\
\text { (watt) }\end{array}$ & \multicolumn{3}{c}{$\mathbf{r}^{2}$ untuk Orde } & $\begin{array}{c}\text { Orde } \\
\text { terpilih }\end{array}$ \\
\hline 3 & $1: 05$ & 0 & 0,8941 & 0,9574 & 0,8808 & 1 \\
& $1: 08$ & & 0,9205 & 0,9543 & 0,8693 & 1 \\
& $1: 10$ & & 0,9152 & 0,9862 & 0,9467 & 1 \\
& $1: 05$ & 30 & 0,6733 & 0,9743 & 0,8542 & 1 \\
& $1: 08$ & & 0,6417 & 0,9445 & 0,8712 & 1 \\
& $1: 10$ & & 0,6282 & 0,9413 & 0,6990 & 1 \\
5 & $1: 05$ & 0 & 0,9483 & 0,9064 & 0,7956 & 0 \\
& $1: 08$ & & 0,7651 & 0,9419 & 0,9861 & 2 \\
& $1: 10$ & & 0,8995 & 0,9394 & 0,9427 & 2 \\
& $1: 05$ & 30 & 0,6138 & 0,9450 & 0,6935 & 1 \\
& $1: 08$ & & 0,5899 & 0,7737 & 0,7331 & 1 \\
& $1: 10$ & & 0,6357 & 0,7580 & 0,8530 & 2 \\
10 & $1: 05$ & 0 & 0,7045 & 0,8604 & 0,9612 & 2 \\
& $1: 08$ & & 0,8000 & 0,9119 & 0,9692 & 2 \\
& $1: 10$ & & 0,6774 & 0,8078 & 0,9181 & 2 \\
& $1: 05$ & 30 & 0,6952 & 0,8551 & 0,9600 & 2 \\
& $1: 08$ & & 0,7827 & 0,8798 & 0,9320 & 2 \\
& $1: 10$ & & 0,5742 & 0,6712 & 0,7618 & 2 \\
& orde rata-rata & & 0,7422 & 0,8894 & 0,8682 & 1 \\
\hline
\end{tabular}

Dari hasil percobaan dapat dicari kinetika reaksinya yang meliputi orde reaksi dan tetapan laju reaksi (k). Hasilnya dapat dilihat pada Tabel 4 dan 5. Dari Tabel 4 terlihat bahwa dari hasil rata-rata koefisien determinasi orde satu memberikan nilai $\mathrm{r}^{2}$ terbesar, dan dari nilai rata-rata orde terpilih, muncul orde satu, sehingga reaksi oksidasi besi kompleks zat organik mengikuti orde pertama-semu dalam konsentrasi Fe-EDTA. Artinya perubahan konsentrasi besi kompleks zat organik mempengaruhi laju penurunan konsentrasi besi kompleks zat organik. Sedangkan konsentrasi $\mathrm{H}_{2} \mathrm{O}_{2}$ dan atau tanpa sinar UV yang digunakan jumlahnya sangat berlebih sehingga konsentrasinya tidak berubah secara nyata selama proses oksidasi. 


\section{Rohmatun, Dwina Roosmini \& Supriha nto Notoda rmojo}

Dari penentuan orde reaksi untuk penurunan konsentrasi Fe-EDTA diperoleh bahwa orde terpilih adalah orde pertama-semu, dan untuk penentuan konstanta laju rekasi (k) digunakan persamaan yang sama dengan mencari orde reaksi.

Dari Tabel 5 terlihat bahwa semakin besar $\mathrm{H}_{2} \mathrm{O}_{2}$ dengan atau tanpa sinar UV tidak meningkatkan nilai $\mathrm{k}$, hal ini disebabkan pemberian $\mathrm{H}_{2} \mathrm{O}_{2}$ yang melebihi dosis optimum akan menyebabkan autodekomposisi dari hidrogen peroksida menjadi oksigen dan air. $\mathrm{H}_{2} \mathrm{O}_{2}$ yang berlebih akan bereaksi dengan $\mathrm{OH}$ radikal dan membentuk hidroperoksil radikal yang kurang reaktif dibandingkan dengan $\mathrm{OH}$ radikal [9]. Karena kurang reaktif maka laju oksidasi menjadi menurun jika $\mathrm{H}_{2} \mathrm{O}_{2}$ berlebih.

Dari Tabel 5 juga dapat dilihat bahwa semakin kecil konsentrasi besi total awal maka semakin besar nilai k, karena beban oksidasi lebih kecil jika konsentarsi kontaminan kecil. Selain itu semakin kecil konsentrasi besi total awal maka reaksi semakin cepat, hal ini sesuai dengan teori Keenan, et al. [10] bahwa nilai $\mathrm{k}$ semakin besar maka reaksi semakin cepat dan nilai $\mathrm{k}$ semakin kecil maka reaksi akan semakin lambat.

Tabel 5 Nilai k untuk persen penurunan Fe-EDTA.

\begin{tabular}{ccccc}
\hline $\begin{array}{c}\text { Feawal } \\
\text { (mg/l) }\end{array}$ & $\begin{array}{c}\mathbf{F e}: \mathbf{H}_{\mathbf{2}} \mathbf{O}_{2} \\
(\mathbf{m o l} / \mathbf{m o l})\end{array}$ & $\begin{array}{c}\text { UV } \\
\text { (watt) }\end{array}$ & Persamaan & $\begin{array}{c}\mathbf{k} \\
\text { (1/menit) }\end{array}$ \\
\hline 3 & $1: 05$ & 0 & $\mathrm{y}=-0,0044 \mathrm{x}-2,2651$ & 0,0101 \\
& $1: 08$ & & $\mathrm{y}=-0,0045 \mathrm{x}-2,2034$ & 0,0104 \\
$1: 10$ & & $\mathrm{y}=-0,0041 \mathrm{x}-2,2073$ & 0,0094 \\
& $1: 05$ & 30 & $\mathrm{y}=-0,0293 \mathrm{x}-2,2748$ & 0,0675 \\
& $1: 08$ & & $\mathrm{y}=-0,0436 \mathrm{x}-2,2637$ & 0,1005 \\
& $1: 10$ & & $\mathrm{y}=-0,0436 \mathrm{x}-2,2637$ & 0,1005 \\
& & & & \\
& $1: 05$ & 0 & $\mathrm{y}=-0,0039 \mathrm{x}-1,8958$ & 0,0090 \\
5 & $1: 08$ & & $\mathrm{y}=-0,0035 \mathrm{x}-2,0203$ & 0,0081 \\
& $1: 10$ & & $\mathrm{y}=-0,0034 \mathrm{x}-1,9704$ & 0,0078 \\
& $1: 05$ & 30 & $\mathrm{y}=-0,0374 \mathrm{x}-2,0262$ & 0,0862 \\
& $1: 08$ & & $\mathrm{y}=-0,0205 \mathrm{xx}-2,1786$ & 0,0472 \\
& $1: 10$ & & $\mathrm{y}=-0,0172 \mathrm{x}-2,126$ & 0,0396 \\
& & & & \\
10 & $1: 05$ & 0 & $\mathrm{y}=-0,0028 \mathrm{x}-1,7927$ & 0,0065 \\
& $1: 08$ & & $\mathrm{y}=-0,0024 \mathrm{x}-1,7449$ & 0,0055 \\
& $1: 10$ & & $\mathrm{y}=-0,0023 \mathrm{x}-1,7556$ & 0,0053 \\
& $1: 05$ & 30 & $\mathrm{y}=-0,01 \mathrm{x}-1,8091$ & 0,0230 \\
& $1: 08$ & & $\mathrm{y}=-0,0083 \mathrm{x}-1,7427$ & 0,0191 \\
& $1: 10$ & & $\mathrm{y}=-0,0075 \mathrm{x}-1,8484$ & 0,0173 \\
\hline
\end{tabular}

Dari reaksi oksidasi ini akan dihasilkan Fe (III) yang mudah untuk diproses pada pengolahan selanjutnya. Hasil dari pembentukan Fe (III) menghasilkan orde yang berbeda dengan penurunan Fe (II) komoleks zat organik, yaitu orde 
nol. Hal ini dapat terjadi karena pembentukkan Fe(III) berasal dari Fe(II) yang telah terlepas dari ikatan kovalen koordinasi dengan EDTA. Sehingga pembentukan $\mathrm{Fe}(\mathrm{III})$ tidak dipengaruhi konsentrasi besi kompleks zat organik awal tetapi dipengaruhi oleh Fe(II) baik menggunakan UV atau tidak.

Diduga reaksi yang terjadi merupakan reaksi bertahap, yaitu:

\section{Untuk reaksi tanpa UV:}

$\mathrm{Fe}-\mathrm{R}+\mathrm{H}_{2} \mathrm{O}_{2} \rightarrow \mathrm{Fe}(\mathrm{II})+\mathrm{RH}$

$\mathrm{Fe}(\mathrm{II})+\mathrm{H}_{2} \mathrm{O}_{2} \rightarrow \mathrm{Fe}(\mathrm{III})+\mathrm{OH} \bullet+\mathrm{OH}^{-}$

$\mathrm{OH} \bullet+\mathrm{RH} \rightarrow \mathrm{CO}_{2}+\mathrm{H}_{2} \mathrm{O}+$ garam mineral (jika reaksi sempurna)

\section{Untuk reaksi dengan UV:}

$\mathrm{H}_{2} \mathrm{O}_{2}+\mathrm{UV} \rightarrow 2 \mathrm{OH} \bullet$

$\mathrm{Fe}-\mathrm{R}+\mathrm{OH} \bullet \rightarrow \mathrm{Fe}(\mathrm{II})+\mathrm{RH}$

$\mathrm{Fe}(\mathrm{II})+\mathrm{OH} \bullet \rightarrow \mathrm{Fe}(\mathrm{III})+\mathrm{OH}^{-}$

$\mathrm{OH} \bullet+\mathrm{RH} \rightarrow \mathrm{CO}_{2}+\mathrm{H}_{2} \mathrm{O}+$ garam mineral (jika reaksi sempurna)

Hal ini dibuktikan dengan analisa jika Fe(II) digabung dengan Fe-R maka orde yang dihasilkan untuk penurunan Fe-R orde satu dan orde untuk pembentukan Fe(III) tetap orde nol.

Tabel 6 Hasil oksidasi pada air sumur di daerah Bandung.

\begin{tabular}{lccccccc}
\hline \multirow{2}{*}{ Air sumur } & Fe Total & \multicolumn{2}{c}{$(\mathbf{m g} / \mathbf{l})$ akhir } & \multicolumn{2}{c}{ \%R } & \multicolumn{2}{c}{ Zat organik (mg/l) } \\
\cline { 2 - 8 } & $\mathbf{( m g / l )}$ & $\mathbf{F e}^{\mathbf{+}}$ & $\mathbf{F e}-\mathbf{R}$ & $\mathbf{F e}^{\mathbf{3}^{+}}$ & $\mathbf{F e}-\mathbf{R}$ & awal & akhir \\
\hline Cibiru-1 & 4 & 3,04 & 0,96 & 157,75 & 65,45 & 11,58 & 2,96 \\
Cibiru-2 & 1,74 & 1,45 & 0,28 & 71,90 & 67,73 & 4,5 & 0,00 \\
Buahbatu & 2,89 & 2,66 & 0,23 & 25,59 & 70,18 & 7,86 & 4,58 \\
\hline
\end{tabular}

Reaksi oksidasi menggunakan kombinasi $\mathrm{H}_{2} \mathrm{O}_{2}$-UV $3 \times 10$ watt ini kemudian diujikan air asli yang berasal dari tiga sumur di daerah Bandung. Hasilnya seperti terlihat pada Tabel 6. Dari Tabel 6 terlihat persen penurunan besi kompleks zat organik sekitar $67 \%$. Hal ini berbeda dengan saat penelitian menggunakan besi artifisial karena dalam air sumur selain besi kompleks zat organik juga terdapat kontaminan lain yang dapat mempengaruhi oksidasi besi kompleks zat organik, misalnya: adanya ion karbonat. Selain besi kompleks zat organik, kandungan zat organik pada air sumur juga ikut turun. 


\section{Kesimpulan}

Konsentrasi besi total awal, $\mathrm{H}_{2} \mathrm{O}_{2}$, UV mempunyai pengaruh terhadap reaksi oksidasi besi kompleks zat organik. Kombinasi antara $\mathrm{H}_{2} \mathrm{O}_{2}-\mathrm{UV} 3 \times 10$ watt akan menghasilkan persen penurunan besi kompleks zat organik lebih besar (99\%) daripada hanya menggunakan $\mathrm{H}_{2} \mathrm{O}_{2}$ saja (84\%). Selain itu waktunya lebih cepat dan dosis $\mathrm{H}_{2} \mathrm{O}_{2}$ yang digunakan lebih kecil.

Penurunan besi kompleks zat organik baik menggunakan oksidasi dengan $\mathrm{H}_{2} \mathrm{O}_{2}$ atau dengan $\mathrm{H}_{2} \mathrm{O}_{2}+\mathrm{UV}$ akan menghasilkan orde pertama-semu. Nilai $\mathrm{k}$ penurunan besi kompleks zat organik dengan kombinasi $\mathrm{H}_{2} \mathrm{O}_{2}$-UV $3 \times 10$ watt lebih besar $\left(0,0053-0,0104\right.$ menit $\left.^{-1}\right)$ daripada hanya menggunakan $\mathrm{H}_{2} \mathrm{O}_{2}$ saja $\left(0,0173-0,1005\right.$ menit $\left.^{-1}\right)$.

Oksidasi menggunakan $\mathrm{H}_{2} \mathrm{O}_{2}+\mathrm{UV} 3 \times 10$ dapat diterapkan pada air sumur di ketiga daerah di Bandung dengan rata-rata persen penurunan besi kompleks zat organiknya $67 \%$ (untuk besi total awal 1,74-4 mg/l). Oksidasi besi dengan kombinasi $\mathrm{H}_{2} \mathrm{O}_{2}$-UV $3 \times 10$ watt akan memberikan prospek yang bagus yaitu dapat dapat digunakan sebagai pengolahan awal (pre-treatment) terhadap air sumur yang mengandung kadar besi yang tinggi dan sulit teroksidasi dengan pengolahan biasa.

\section{Saran}

1. Perlu penelitian lebih lanjut tentang zat organik yang kompleks dengan zat besi.

2. Perlu dikontrol kualitas air dengan parameter lainnya seperti kandungan Mangan (Mn) Karena keberadaannya di dalam air tanah biasanya selalu ada dengan besi $(\mathrm{Fe})$ dan mangan lebih sulit untuk dioksidasi disbanding besi.

3. Perlu penelitian dengan variasi yang lebih banyak untuk mengetahui faktor lain yang mempengaruhi reaksi oksidasi besi seperti jarak sinar UV, temperatur, dan $\mathrm{pH}$.

\section{Daftar Pustaka}

[1] Montgomery, J.M., Water Treatment Principles and Design, John Willey and Sons, 1985.

[2] Said, N.S., Kesehatan Masyarakat dan Teknologi Peningkatan Kualitas Air, Direktorat Teknologi Lingkungan Deputi Bidang Teknologi Informasi, Energi, Material, dan Lingkungan, Badan Pengkajian dan Penerapan Teknologi, 1999.

[3] Hariawan, S.W. \& Agustina, S., Studi Penurunan Konsentrasi Surfaktan Dengan Oksidasi UV- $\mathrm{H}_{2} \mathrm{O}_{2}$, Jurnal Purifikasi, 5(3), 127-132, Juli 2004. 
[4] Alaerts, G. \& Santika, S.S., Metoda Penelitian Air, Penerbit Usaha Nasional, Surabaya, 1984.

[5] Standar Methods for the Examination of Water dan Wastewater 20th Edition, American Public Health Association, Washington DC, USA, 1998.

[6] Stumm,W. \& J.J. Morgan, Aquatic Chemistry: Chemical Equilibria and Rates in Natural Waters, John Wiley \& Sons, Inc New York 3rd Edition, 1996.

[7] Watts, R.J., Hazardous Wastes: Sources, Pathwaysand Receptors,John Wiley and Sons, Inc, New York, 1999.

[8] Metcalf \& Eddy, Wastewater Engineering Treatment and Reuse, Mc Graw Hill, 2003.

[9] Hawkes, et al., Technique for Monitoring Hydrogen Peroxide Concentration Off-line \& On-line, Water Resources, 34(8), 2191-2198, 2000.

[10] Keenan, et al., Kimia Untuk Universitas, Edisi ke-6, Jilid-1, Penerbit Erlangga, Jakarta, 1984.

[11] Jones, C.W., Application of Hydrogen Peroxide and Derivatives. Published by The Royal Society of Chemistry, Thomas Graham House, science Park, Milton Road Cambridge CB4 OWF, UK, 1999.

[12] Mihelcic, J.R., Fundamentals of Environmental Engineering, John Wiley \& Sons, Inc., 1999.

[13] Sawyer, C.N, McCarty, P.L. \& Parkin, G.F., Chemistry for Environmental Engineering, McGraw-Hill International Edition, 1994. 